European journal of American studies

Special Issue: The North-West Pacific in the 18th and 19th Centuries

\title{
III. The Second Type of Secret Society among the Northwest Americans
}

\section{J.A. Jacobsen}

\section{(Q) OpenEdition \\ Journals}

Electronic version

URL: https://journals.openedition.org/ejas/7812

DOI: $10.4000 /$ ejas.7812

ISSN: 1991-9336

Publisher

European Association for American Studies

Electronic reference

J.A. Jacobsen, "III. The Second Type of Secret Society among the Northwest Americans", European journal of American studies [Online], 5-2 | 2010, document 6, Online since 18 February 2010, connection on 08 July 2021. URL: http://journals.openedition.org/ejas/7812 ; DOI: https://doi.org/10.4000/ejas. 7812

This text was automatically generated on 8 July 2021.

Creative Commons License 


\title{
III. The Second Type of Secret Society among the Northwest Americans
}

\author{
J.A. Jacobsen
}

\section{The Medicine Man and the Kosijut (Shaman).}

1 The type of secret society formed by the medicine men or shamans is called Pak-hallas among the Kwakiutl, or Pak-kwalla, and Allo-kwalla among the Bella Coola. ${ }^{1}$ Found on the Northwest Coast of America as well as in Siberia, they can be divided into two classes. One class is formed by those who heal illnesses, the other by those who distinguish themselves before the people through miracles and fortune telling.

2 They perform all their deeds not through their own power, but through the magic of obliging, divine spirits who are at their disposal, and only through their help can the medicine man perform his cure. For according to the common belief of the Indians, each illness and each misfortune comes from evil spirits which can be expelled and made harmless only through well-meaning and mightier good spirits who are welldisposed towards humans. Among all coastal Indians, each individual medicine man has a special spirit which is devoted to him and is at his disposal on request.

3 The most distinguished of these spirits is called Kle-klati-ê' $\mathbf{1} l^{2}$. He dwells in the forest and it is there that he is sought out by the prospective doctor. When the aspiring medicine man encounters the spirit, he falls down as if dead, though never dies, rather comes to his senses after a while and then starts singing a song, the text and melody of which the spirit has inspired in him. From now on the Indian, inspired by the supernatural spirit, will be a medicine man who will use the magic song that has been entrusted to him in all his cures. However, this song does not serve the shaman in question during his entire lifetime, but changes often, since almost every year he has encounters with his protective spirit in order to learn new songs from it. The Indians visualize the spirit Kle-klati-e'-il in complete human form, but entirely clothed in cedar bark and adorned with many cedar rings of various kinds, one of which the protégé receives as a gift now and then. 
4 A second, also very powerful spirit is the Kle-sat-pli-lánna, which, according to a version of the Bella Coola Indians, first brought fire to humans. Others ascribe this deed to the Raven. For this reason one often sees the medicine men, inspired by this spirit, jump through fire, swing back and forth over fire on ropes, eat fire (called Nunlehis-stalath among the Kwakiutl), lick glowing iron, and so on, through which they demonstrate at the same time to their fellow tribesmen their legitimacy and their inspiration through that spirit. This spirit also warns its chosen medicine man of approaching war by uttering the war cry of the Bella Coola "Vüh, vüh, vüh, vüh." When the medicine man hears this call in the forest, he immediately runs to the village and gives the alarm.

5 A third spirit is the Skaia which usually lives in the streams in the form of a salmon and is sought out there by the "novices." If a medicine man who is inspired by the Skaia spirit performs some kind of cure in a house, during which, as all medicine men, he sings and dances, everyone who approaches the house and hears the song will turn back. For should someone pass the house in question during such an act, the Indian is convinced that he would be punished by the Skaia spirit and immediately drop dead.

6 Since this is commonly known, no one dares pass a house where a medicine man performs a cure, since no one can know whether the medicine man is inspired by the Skaia spirit or some other spirit.

7 In the various tribes there may still be other spirits which inspire the medicine men, but these are not equal in power or standing to the three mentioned above.

8 As among many primitive peoples, the spirits of deceased family members also play an important role in the cults of the Northwest Indians. This is especially the case among the medicine men, since it is commonly believed that the spirit of a deceased medicine man returns.

9 The Indians claim that all deceased good people go the greatest of all spirits, the true god A'lkonda'm. Through his servant named Dam-dam-kli'msta, chosen individuals are sent back to Earth to be reborn by a maternal relative. A person can return several times. Such people are called "Aïlt kwákem Dam-dam-kli'msta" (that is, the good person who has returned with the help of Dam-dam-kli'msta). Among the Kwakiutl people who are thus reborn are called Kla-kajo't-se. But most of the deceased remain with A'lkonda'm and support or oppose from there the people who live on Earth. Such spirits of deceased forefathers, who are at the disposal of the medicine men, are called Kóll-klūlle'm. They are recognizable to the living Kosijut in that they have a blue face and no hair on their head. As a sign that one of the Kóll-klūlle'm has selected him to be a medicine man, the chosen one hears a four-note whistling in the forest. Scarcely has the last note faded away, when the candidate falls face-down to the ground and remains lying there for a long time. As soon as he stands up, he is a full-fledged medicine man.

10 Now and then a Kóll-klūlle'm also visits the house of a living relative and requests from this person (according to the instruction of the Kosijut) food, clothing, and the like as an offering. The requested objects are immediately thrown into the fire by those making the offering.

11 I will provide a song of a medicine man who is inspired by Kóll-klūlle'm:

1.

Sa koll klulem sü dich 
alla silk ti mot

dik spostemsent dai

sup toss señemll

di nok saitimot skida.

2.

Sauart nu kemiken dopko

Die otti sijul dai

Jau dalt kik meinof dam

do ill kli kwanoml to man.

3.

Was nuskki mi sulsko

La kos sloll lullemch

tioti ne mosstos

Si bon kemmem

dnie soe kik die motsen

die as ko wandot dich.

4.

Was alpik malustuskos

Saijul ai killa

sie Kosijut dalits sos

die pa kossoma allim

alla kole kal jei sllats.

Translation:

1.

How is it supposed to be with the dead,

for the deceased wish

that the spirit should play his flute to all

living people, so that these soon die.

2.

The good spirit helps me to overcome the evil spirit.

With the good spirit I can place the evil spirit

with its head down and its feet up.

3.

Kos-sloll-lullemch (the name of the doctor singing)

does not wish the spirits of the deceased

to stick their heads out of the earth,

therefore he lays or charms stones onto the

head of the evil spirit so that it

remains under the ground.

4.

Sajul ${ }^{3}$ wishes that I put the ceremonial dress

on my body

when my spirit

goes to A'lkonda'm's house to dance.

12 The spirits of the deceased, Kóll-klūlle'm, assist not only at healings, but also with prophesying and other activities of medicine men. Thus, they announce, for example, the arrival of the fish, when in February or March the stint (eulachon or candle fish) visit the fjords and stream mouths in countless numbers for spawning. The shaman then usually reports that he has just seen the Kóll-klūlle'm with a large chest fishing on the river bank, and summons the people to begin fishing. It is supposed never to have occurred that a medicine man gave the people a false report on the arrival of the fish.

There are supposed to have been medicine men among the Bella Coola who were inspired by all four of the above-mentioned spirits. But a privilege of this type only rarely occurs. Also, women are occasionally chosen by a spirit to be a shaman. But 
they too must undergo the same religious tests as the men in order to establish credibility among their tribesmen. Among some tribes of the Kwakiutl, the spirit Lülūlă-lă is regarded as a good inspirer and protective spirit of medicine men. Among others, the spirit Ma-ma-k'ă has this reputation. During the dance, the spirit carries a special staff. ${ }^{4}$ When he turns this staff, people fall down as if dead. But the spirit frequently enlivens them again. However, since both these deities also serve as tribal ancestors in some communities, they may be considered as belonging to the abovementioned Kóll-klūlle'm spirits.

14 Of the remaining spirits which serve as inspiration to the medicine men among the Kwakiutl, I have been able to learn but little. No definite age is set at which the one who is called by the spirit must enter his office. It appears to depend more on the will of the individual or on outside circumstances. It is customary in such cases that the one prospective medicine man must first give a large feast for which he provides food and drink in abundance and performs a dance which the guests accompany with songs to a drum beat. ${ }^{5}$ A medicine man may dance and sing as much as he wants, and especially as often as the spirit comes to him, which usually happens every two to four weeks, and finally, every time he is called to a sick person. Such medicine dances are called Hay'a-likala'th by the Kwakiutl. If there are not enough earthly singers present to support him during these dances, he is, according to legend, helped by some spirits previously conjured from the earth and appearing as suddenly and invisibly as they disappear.

15 The medicine men of the Bella Coola and the neighboring tribes have, just as those of the Eskimos and the Asiatic peoples, the rare quality that their souls leave their bodies from time to time. This is supposed to happen when the medicine man thinks very hard about the cause of an illness or an accident.

16 If a medicine man is called in case of illness he usually packs up his entire magic paraphernalia into a chest which is stored either in his house in a room constructed for this purpose or hidden by him in the forest.

17 His utensils consist of hand rattles, mostly in the form of a bird, on which an otter is frequently placed as well. For the otter is the most frequent symbol of medicine men, since the inspired spirit in its dealings with the medicine man takes on the form of this animal. Other magic paraphernalia are a head ring of woven red-colored cedar bark and several arm rings and neck rings, mostly with monsters carved of bone or stone hanging from them which presumably contain the spirits. Very frequently, and especially among those medicine men who have inherited the spirit as well as the paraphernalia from their fathers, there are long bone rods on these rings which the medicine men pass through their hair which hangs down their back. (Among the coastal Indians, only the medicine men are permitted to wear long hair.) On their chests, the medicine men also wear various other bone implements which are in part also used for "combing" and in part serve as magic containers into which the medicine man banishes the soul of an enemy so that the person must die. When travelling, the medicine man takes a stone, bone, or wooden lizard with him which is bound to the mast as an amulet against danger at sea. For a fee, these amulets are also loaned to people who go on a dangerous trip.

18 After having seen the sick person, the medicine man often has water brought to him, takes a mouth full of it, and sprays it into the face of the sick person. He then puts on his head- and neck rings, takes his rattle in hand, and performs a wild dance around 
the patient. ${ }^{6}$ At the same time he lets resound the song which his protective spirit inspired in him. Its text indicates to the listeners the difficult struggle of the shaman with the evil spirit which possesses the sick person. One often hears requests from the mouth of the shaman, sometimes also a bitter reviling of the evil spirit. For, according to the rock-solid belief of all Indians, it is from such [evil spirits] alone that all illness and misfortune which strikes a person comes, and not at all from an accidental external cause. After the medicine man has danced around the sick person for a while to monotonous singsong, he begins to animatedly massage the afflicted body parts (as a result of which, in many cases, the illness becomes even worse), takes another mouthful of water, bends over the sick person and appears to suck with powerful draughts on the painful spot. After a few minutes he spits out blood, or often, in an extremely skillful way, seems to suck from the body of the sick person bones, shards, tree bark, stones, animal claws, fish bones, thorns, and the like, which, as is often assumed, have been charmed into the body of the sick person by a rival or evil spirit.

19 A fur dealer from west Vancouver [Island], who had frequently observed the cures of the medicine men, reported the following to me: "Once a medicine man, who was wellknown because of his particular procedures, was fetched to attend to a case of illness. He began the usual song and dance for such cases for the sick person. Then he began to suck on the body of the sick person and finally suddenly jumped up shouting: 'Hold me tight,' Clutching both hands convulsively together and angrily wringing with the people who held him, he was-struggling in violent opposition-dragged to the sea and tossed in head first [by the spirit]. He immediately reappeared, but with open hands, to show that he had left the illness on the bottom of the sea."

20 Often a villager who mistrusts a medicine man is accused of having motivated another medicine man through payment to inflict the sick person with the evil. How ingrained this belief is, is shown by an example which was told to me by a missionary: "On the east coast of Vancouver [Island] lived a missionary, who had already baptized several young Indians and erected a small school. Among his students was an intelligent youth of about 18 years who, because of his industry and his obedience, was the favorite of the missionary. One day the youth was missing from school. Upon the missionary questioning the other students, they said he was sick, whereupon the missionary sought him out. After a long conversation it transpired that the student had become angry with a medicine man who lived in the region, and that the latter had threatened the youth, saying he would die within six weeks. The youth took this threat so much to heart that he believed himself deathly ill, although the missionary took the greatest pains to convince him otherwise. He did actually die, before the six weeks had passed, in the opinion of the missionary merely from anxiety about the vindication of the threat of the medicine man."

21 As payment for a visit to a sick person the medicine man receives woolen blankets worth two to five dollars.

22 As among the Bella Coola the shamans play a large role in medical matters among the more northerly dwelling Tlingits of YakutatBay and the Copper River. Up there, when healing sickness and especially when prophesying, they wear, similar to the Eskimos in Alaska, special wooden masks, each of which represents a serving spirit.

23 Among some tribes the body of the medicine man is burned. Among others, however, for example the Tungas, it is entombed in a purpose-made house with all his possessions and his charms (if he has no relative who inherits his office). I have 
frequently heard the Indians tell, that the hair and fingernails of a famous medicine man, who had been entombed in this manner, grew longer every year.

The second class of medicine men is formed by those who are occupied less with the healing of illnesses than with various kinds of miracles, through which they wish to prove their inspiration from the high spirits. One of them is a medicine man called Kem-ka-la-tla, or the one who tames Hamatsa, when the latter have wounded an onlooker with their bite. Because of their powerful protective spirit, these people are called "Kosijut" by the Bella Coola. Kosijut himself, according to legend, is supposed to live in a glacier located in the area. But he appears to be only an embodiment of the moon, since the Indians always make mention of him in connection with the moon. The specialty of the priests or medicine men of this god is to let themselves be burned on a high funeral pyre, slit open their bodies so that the intestines hang out, have their heads cut off, lick glowing iron, etc. Because of their unique form and color combinations, the masks of these medicine men are of quite special interest. They are the most beautiful and most original I have seen anywhere in northwestern America. If an eclipse of the moon occurs, the Indians say that the moon (En-kla-loi'-killa) performs a Kosijut dance. They believe that its darkening comes from the fact that, for the dance, it has painted its face too black. Therefore each Indian who performs the Kosijut dance must also blacken his face for the night dance. If this rule is not followed or if even just one unpainted fleck is found on his face, it is believed that a misfortune will happen to the dancers.

25 For this reason, the Indians observe the moon during an eclipse most precisely. If it shows white flecks, then it has thrown its face color onto someone among them, and that person is then mercilessly condemned to die.

26 The Kosijut novice is not permitted to take off his cedar bark rings during the entire time of the ceremony. He must also always be serious and, above all, betray nothing of the secrets of the society to an uninitiated person; otherwise he would surely be killed through some kind of magic by the older medicine men.

27 Like all other festivals of the gods, the Kosijut performance can take place only during the two winter months of December and January. If a medicine man can no longer help a sick person, he sends him in certain cases directly to the god Kosijut, as the following story shows.

28 Once upon a time, there lived a man in Bella Coola Fjord whose entire body was covered with wounds. He visited various medicine men of the region, but none could help him. At last, an old medicine man came from far away and told him to go to the ice palace of the god Kosijut and lie down under the ice wall there. The sick man decided to follow this advice, and, accompanied by his brother, he went into the high mountains. He lay down, as he had been advised, under the ice wall. And indeed, immediately large pieces of ice began to fall down, but neither he nor his brother was struck by them. After a while the falling ice stopped, the glacier opened up and out walked the god Kosijut. He asked the Indians why they had disturbed his rest. So the sick man told him about his suffering and said that only because of this had he dared to come to the palace of the gods. "If this is so," responded the god in a friendly manner, "you and your brother may come in." He led them into a mighty ice hall in which the light shimmered blue, presented them with many blankets and other things, and at last spoke to the sick man thus: "I will heal you, but you must promise me that you will marry only after four years. If you do it before this time, you must die." Then the god 
Kosijut stroked the body of the Indian with his hand and immediately the man was free of all wounds. The man thus healed cheerfully returned to his home with his brother. But, to his misfortune, he did not keep his promise. Rather he married shortly after his return. Upon this the word of the god came true and he died.

29 As mentioned above, those belonging to the Kosijut society are primarily accustomed to produce deeds of wonder for the public. One of the most popular is when they burn themselves. A procedure of this type was described to me by an Irishman, who had lived there on the coast a long time, in the following way. A famous medicine man (belonging to the Kosijut society) had made it known among the Tsimshian Indians that he would have his living body burned up. Fellow tribesmen from far and wide gathered there to witness the spectacle. A large pile of wood was erected in a clearing and then set ablaze. Then the medicine man climbed into a chest that had been prepared. It was raised up by four Indians and, amid horrible death songs, placed in the flames. In the middle of the fire the medicine man could still be seen and heard continuing with his horrible song, until finally the rising flames seized the hair of his head and the chest collapsed to ashes. A similar spectacle was carried out in Europe in 1886 by Bella Coola Indians spending time there, in which a Kosijut staying with a troop showed his art to the public. The man managed to escape from the chest, which had been fitted with a trap door, through a vault, which the Indians had dug during the night. From the vault, he held up an artistically carved head, mounted on a pole, made especially for that purpose, which was quite similar to his own, giving the appearance that the medicine man actually let himself be burnt.

30 Members of the Kosijut society have to help each other with the production of this carved wooden head and with the digging of the vault, which can be as long as 100 meters. Should an uninitiated person come across the secret through some accident, he is immediately killed so that he cannot betray their deception and thereby undermine their authority among the people.

31 Another popular performance is one in which they let a colleague cut open their body with a knife or a lance and thus mutilated run through the house, dragging behind them the intestines which have spilled out. (This trick was performed in Bella Coola Fjord in the winter of 1890.)

32 It also happens that they let their bodies be pierced with a spear so that the point protrudes from their back. In order to make the trick believable, the bearer of the spear must move it back and forth, whereby the point protruding from the back must of course move along with the shaft in front.

33 I was told the following story about the Tlingits on the Copper River by a fur handler who lived there: A ship from San Francisco, which used to come to the Copper River once a year to acquire provisions and trade goods, as well as bartered furs, stayed there for weeks, sometimes months. A famous shaman, who lived on the Copper River, offered to prophesy what would happen to the ship. The trader made no objections to this and a feast was arranged, during which the shaman appeared in eight different masks. The last part of the spectacle was a fire test. A large fire was built in the house and the shaman had a rope of cedar bark fastened to his feet and arms. A number of Indians seized both ends of the rope and swung the shaman back and forth over the fire. The rope soon began to burn and eventually tore, so that the shaman fell right into the fire. But he jumped out of the blaze so quickly that not even the smallest burn marks were to be found on his body. Thereupon he stated that the ship had run 
aground and would never return again. And so it actually happened, and since that time the prestige of the shaman has been growing.

To end the report, we will provide another Kosijut song.

I.

Kil kosta sametsen dai

jau di wan Kwalusem dai

die dek do kennol sut dai

II.

Sauwaik dok-sai allei au

was Kwalt-kwaltŭn sanau

Si nu pollas ats.

wau aksknemtenem ski ats,

jo all die sejul dau.

III.

Jau i wayil kwalutsen,

ai jau skolakem klem

Sio eklanni lai.

Silkolankta nau ats.

Si anus jaŭts slem

Batallo sai jai ko ats.

Translation

1.

I see you coming, Dance Spirit,

however, you always come rather late.

You speak and send messengers to me,

you great Dance Spirit.

2.

Now I see the spirit coming,

Everyone, come here and see my mask.

But first I want to hear our song

of "Skakva" (the devil fish).

3.

Now they are fetching the food brought here

and fill my stomach with it.

But a small bird (by the name of Mok-Mok)

is also hungry

and wants to eat.

35 To this day, I have not fully succeeded in finding a direct connection between the medicine man ("Alo-kwalla") and the Kosijut or magician, though all those with knowledge of secret societies indicate that both are spiritually closely related, and in fact I also believe that both only represent subdivisions of one and the same caste, just as various subdivisions are also found among the Hamatsa. Also, it is not impossible that the Hatsikwallà among the Kwakiutl, called Haúwin-álla by the Bella Coola, have a certain connection with the Kosijut.

36 There may exist many close connections between the various organizations and many relationships and similarities in the ceremonies, in the paraphernalia and religious ideas, about which we still have no clue. Mythology, worship, and superstition everywhere, at all times, and among all peoples offer the most varied and difficult problems in ethnological research, and this holds true even more in cases where these ideas are not common property of the general population, but a zealously protected secret of an elite class. 


\section{NOTES}

1.This article was first published as "Der zweite Typus der Geheimbünde bei den Nordwest-Americanern" in Zeitschrift für Ethnologie 26:104-115, 1894.

2.The following description refers only to the Bella Coola.

3.Sajul is the thunder god of the Bella Coola who lives in the mountains.

4.Magic staffs are definitely in use among the Haida medicine men. Thus, for example, the story of a spirit who visits the earth as a medicine man and, after he completes his work, lies down inside the earth where he supports the crust of the earth with a magic staff, since otherwise it would sink into the sea.

5.The large wooden drum is used among the Haida, Kwakiutl, and related tribes, while the Ahts of west Vancouver [Island] preferably used in their cures a castanet-like drum covered with animal skin.

6.There are medicine men who undertake their healing without a rattle. 